\title{
Where has the rum gone? The impact of maritime piracy on trade and transport
}

\author{
Alexander Sandkamp ${ }^{1}$ (D) Vincent Stamer ${ }^{2} \cdot$ Shuyao Yang $^{3}$
}

Accepted: 2 September 2021 / Published online: 8 October 2021

(c) The Author(s) 2021

\begin{abstract}
Despite a general agreement that piracy poses a significant threat to maritime shipping, empirical evidence regarding its economic consequences remains scarce. This paper combines firm-level Chinese customs data and ship position data with information on pirate attacks to investigate how exporting firms and cargo ships respond to maritime piracy. It finds that overall exports along affected shipping routes fall following an increase in pirate activity. In addition, piracy induces firms to switch from ocean to air shipping, while remaining ocean shipments become larger. At the ship-level, the paper provides evidence for re-routing, as container ships avoid regions prone to pirate attacks.
\end{abstract}

Keywords Trade $\cdot$ Transport $\cdot$ China $\cdot$ Piracy $\cdot$ Container Shipping

JEL Classification F14 $\cdot$ F19 $\cdot$ N70 $\cdot$ R41

We would like to thank two anonymous referees and the editor, Lindsay Oldenski, for excellent comments and suggestions, as well as Gabriel Felbermayr for his support throughout this project. We are also grateful to participants of the ifo Center for International Economics Internal Seminar and the ifo Center for Industrial Organization and New Technologies Internal Seminar for their helpful comments and suggestions as well as to Falk Wendorff for excellent research assistance.

Alexander Sandkamp

sandkamp@economics.uni-kiel.de

Vincent Stamer

vincent.stamer@ifw-kiel.de

Shuyao Yang

shuyao.sy.yang@gmail.com

1 University of Kiel (CAU), Kiel Institute (IfW) \& KCG, Wilhelm-Seelig-Platz 1, 24118 Kiel, Germany

2 University of Kiel (CAU), Kiel Institute (IfW) \& KCG, Wilhelm-Seelig-Platz 1, 24118 Kiel, Germany

3 ifo Institute - Leibniz Institute for Economic Research at the University of Munich \& LMU Munich, Poschinger Str. 5, 81679 Munich, Germany 


\section{Introduction}

With around 200 incidents in 2017 which lead to 166 crew members being taken hostage or kidnapped and three killed, maritime piracy remains a real threat to international merchant shipping (ICC IMB 2018). ${ }^{1}$ Beyond the risk faced by the crew, piracy increases the cost carried by shipping companies, including higher wage premia, a rise in insurance payments due to a lower expected value of a shipment (since it may be damaged or sunk with a higher probability), ransom payments, as well as the actual cost of protecting the ship through military escorts, armed guards, electric fencing, razor wire, water cannons, non-lethal laser or acoustic devices (Towergate Insurance 2018; Gilpin 2009).

Increased fuel and time cost of altering routes can also be substantial. For example, routing around the Malacca Strait-one of the world's busiest sea lanes and frequently prone to pirate attacks-would mean a detour of about 1,000 nautical miles (Berg et al. 2006). In 2021, the blockage of the Suez Canal also meant detours around the Cape of Good Hope, amounting to several thousand miles depending on the destination. Estimates for the direct costs of piracy due to re-routing range from 7 billion USD to 12 billion USD in 2010 (Bowden et al. 2010). ${ }^{2}$

This paper investigates the effect of piracy on trade and transport at the product-, firm- and ship-level. In the first part of the analysis, we combine Chinese firmlevel customs data with data on maritime piracy to investigate how exporting firms respond to piracy induced costs. China is the world's largest exporter and its trade routes pass several areas frequently subject to pirate attacks, including the Suez Canal and the Malacca Strait. Since China trades with all world regions, the effects of piracy on Chinese firms can plausibly be generalised to exporters situated in other countries, too. They certainly matter for importers.

At the 8-digit-product level, we show that exports from China decline on routes affected by piracy. At the firm level, pirate activity on a set of trade routes reduces the frequency of shipments by vessel and induces exporters to switch transportation mode from ocean to air, while remaining average shipments per firm become larger. Even though overall trade recovers around half a year after the piracy incident, the impact on firm behaviour is long lasting. It is, however, only observable for small firms.

In the second part of the paper, we investigate whether piracy indeed induces ships to re-route and to increase cruising speed. To do so, we combine the aforementioned piracy data with high frequency ship position data to show that container

\footnotetext{
1 The reasons for piracy are manifold and include traffic along particular trade routes, economic conditions (Percy and Shortland 2009; Cariou and Wolff 2011), inadequate government action against piracy (Hastings 2009; Chalk 2008), geographic position, weak judicial systems and political instability (Murphy 2007). For an overview, definitions and historical context the reader is referred to Mejia et al. (2012). 2 Indirect costs of piracy range from threatening the participation of neighbouring states in maritime trade, tourism and fishery (Mbekeani and Ncube 2011) to an increase in corruption and thus weakening of the legitimacy of governments and even potentially environmental disasters as pirates attack oil tankers or ships carrying toxic chemicals (Chalk 2008).
} 
ships avoid regions recently subject to pirate attacks. There is also some evidence that if the ships still pass through affected regions, they increase cruising speed.

The paper relates to four strands of literature. The first strand concerns the effects of piracy on trade in general and firms' choice of transport mode in particular. A good overview is provided by Endler et al. (2012), who show that most studies are either descriptive or focus on a particular region. Fu et al. (2010) construct a model of the container liner shipping market in order to investigate the impact of piracy on trade volumes. The authors find that Somali pirates have reduced traffic between Europe and the Far East through the Suez Canal by about 30\%. As only some of this traffic is rerouted via the Cape of Good Hope, the annual loss is estimated to be around 30 billion USD.

Bensassi and Martínez-Zarzoso (2012) estimate a gravity model, finding that 10 additional vessels being hijacked in a given year reduce exports by $11 \%$. Both studies focus on trade between Europe and Asia. This paper extends the scope by considering the universe of Chinese exports to all destination countries to empirically investigate the effects of piracy on ocean and air trade. Moreover, it uses comprehensive data on global container ship positions to investigate how piracy in a given region affects the number of ships in that area.

Bendall (2010) specifically calculates the costs of re-routing ships from the Suez Canal to the Cape of Good Hope using a model of shipping costs. The model incorporates differences between the two routes in the cost of fuel, charter, insurance and transit fees, among others. According to the author, the additional annual costs for commuting vessels amount to around 3.2 million USD for a very large crude carrier or around 2.8 million USD for a 10,040 $\mathrm{TEU}^{3}$ container ship.

Using annual OECD data on maritime transport costs, Bensassi and MartínezZarzoso (2013) estimate the effects of piracy on transport cost. The authors find that the hijacking of one additional ship between Europe and Asia increases transport costs between the two continents by $1.2 \%$. However, the authors do not discuss the implications of such increases in costs on prices and the choice of transport mode. This paper investigates how piracy affects export prices, the choice of shipment mode as well as the size of shipments.

The cost of piracy cannot be modelled as iceberg transport costs because piracy is transport mode specific_-goods shipped by air are not subject to pirate attacks —and accrues per journey, as one military escort or security staff is required per ship, no matter whether the latter runs at full capacity. We therefore consider piracy to affect fixed costs per shipment. Our paper thus relates to the literature linking this specific type of trade cost to frequency and average size of shipments. In particular, we rely on Kropf and Sauré (2014) for the theoretical underpinning of our empirical strategy. Our work also links to Hornok and Koren (2015a), who investigate administrative barriers as a source of fixed costs per shipment as well as Hornok and Koren (2015b), who find per-shipment costs to be negatively associated with shipment frequency and positively associated with shipments size.

\footnotetext{
3 Twenty food equivalent unit.
} 
More broadly, our approach relates to the literature that departs from modelling trade costs taking the iceberg form (see for example Hummels and Skiba (2004) for evidence on transport costs accruing per unit or Friedt and Wilson (2020) for the endogenous nature of transport costs). Our results are also consistent with Békés et al. (2017) who investigate the relationship between uncertainty and shipping behaviour.

The third strand of literature this paper relates to concerns the determinants of firms' choice of transportation mode and has already attracted significant research attention. At the macro level, Hummels (2007) discusses how declining transport costs such as the spread of containerization have contributed to an increase in international trade. Correspondingly, this paper shows that an increase in transportation costs along a set of ocean routes due to pirate activity reduces bilateral trade flows along affected routes.

Harrigan (2010) develops a Ricardian model to investigate the interaction between trade, transport cost and the choice of transport mode and tests its predictions using US import data. Beyond the finding that goods with high unit values are more likely to be shipped by air, the author demonstrates that countries more distant from the destination market have a comparative advantage in lightweight goods. Related to that, Hummels and Schaur (2013) model a firm's choice between air and ocean transportation, showing that more time sensitive goods are more likely to be shipped by air. Ge et al. (2014) use Chinese customs data to investigate the choice of transport mode at the firm-level. The authors find that high productivity firms are more likely to ship goods by air, indicating that they specialise in time sensitive high value products.

Finally, our paper relates to the growing literature exploiting high frequency ship position data derived from the maritime Automatic Identification System (AIS) for economic analysis. Brancaccio et al. (2017) use AIS data to develop a model of bulker shipping that includes search frictions between ships and exporters. Heiland et al. (2019) and Wong and Ziv (2020) use port call data to construct a port network and investigate the effects of a Panama Canal expansion and endogenous trade costs, respectively. Furthermore, Arslanalp et al. (2019), Cerdeiro et al. (2020) and Stamer (2021) use AIS data to approximate international trade flows.

The remainder of this paper is structured as follows. Section 2 outlines a theoretical framework in which the cost of piracy can be modelled. Section 3 presents the data used, while Section 4 discusses the empirical strategy. Section 5 presents the baseline results, followed by several extensions and robustness checks. Section 6 concludes.

\section{Theoretical framework}

In order to guide our estimation, we borrow from Kropf and Sauré (2014). The authors model a trade-off between fixed costs per shipment and storage costs. They show that an increase in the fixed costs per shipment reduces the frequency of shipments while increasing the size of the average shipment. Piracy can be modelled as affecting fixed costs per shipment. For example, costs for military escorts or higher 
wages for the crew increase the cost of a ship's journey. If these additional costs are divided across containers, the costs of shipping an additional container increase from the perspective of the exporter. ${ }^{4}$

The same is true if increased pirate activity induces re-routing of vessels, thus increasing shipping time. For example, a round voyage of a container ship from Singapore to Rotterdam takes on average 33 days if travelling via the Suez Canal and 42 days if travelling around the Cape of Good Hope (Bendall 2010). Such an increase in shipping time also increases the cost per shipment.

Following Kropf and Sauré (2014), one would thus expect that an increase in pirate activity along a particular route is associated with a decline in shipment frequency and an increase in average shipment size. Given that air shipments are a substitute to ocean shipments, one would also expect an increase in air shipments as the cost of shipping by vessel increases.

An alternative channel through which pirate activity may affect trade and the choice of shipment mode is through uncertainty. Békés et al. (2017) show that firms tend to send less frequent but larger shipments to more uncertain markets. Piracy increases uncertainty by increasing the probability of losing a ship at sea. In line with Békés et al. (2017), one would expect to see exporters responding to piracy by reducing the number of shipments while increasing their size.

\section{Data}

To investigate the impact of piracy on trade and the choice of transport mode, this paper uses Chinese customs data, which provides information on monthly export transactions at the firm-product(8 digit)-destination-country level for the period 2000 to 2006. Crucially, for every transaction it also reports the main transport mode employed. While value in USD and quantity are reported directly, unit values are imputed by dividing value by quantity.

The Chinese customs data differentiates between six different modes of transport of which we use "sea and river" and "air". These are by far the most important transport modes, covering $84 \%$ of observations and $88 \%$ of export value in the years 2003 to 2006. In the baseline regression, we abstain from using "rail" and "road" for two reasons. First, transportation by land is restricted primarily to Asia. Second, it may also be subject to armed robberies that may or may not correlate with pirate activity. For the final two modes "mail" and "other", it is not clear how they are transported, which is why they are excluded from the analysis.

Data on piracy is taken from the International Maritime Organisation which provides monthly reports on piracy incidents (allegedly committed and attempted attacks) in 13 different geographical areas. Figure 1 shows the total number of incidents between 2000 and 2020. Due to the limitations of the customs data, we have to restrict our analysis to the period 2000 to 2006. In contrast, satellite coverage of ship

\footnotetext{
4 The term "shipment size" in this paper refers to the size of the transaction reported in the customs data. It is not the same as the amount of goods carried by a ship.
} 


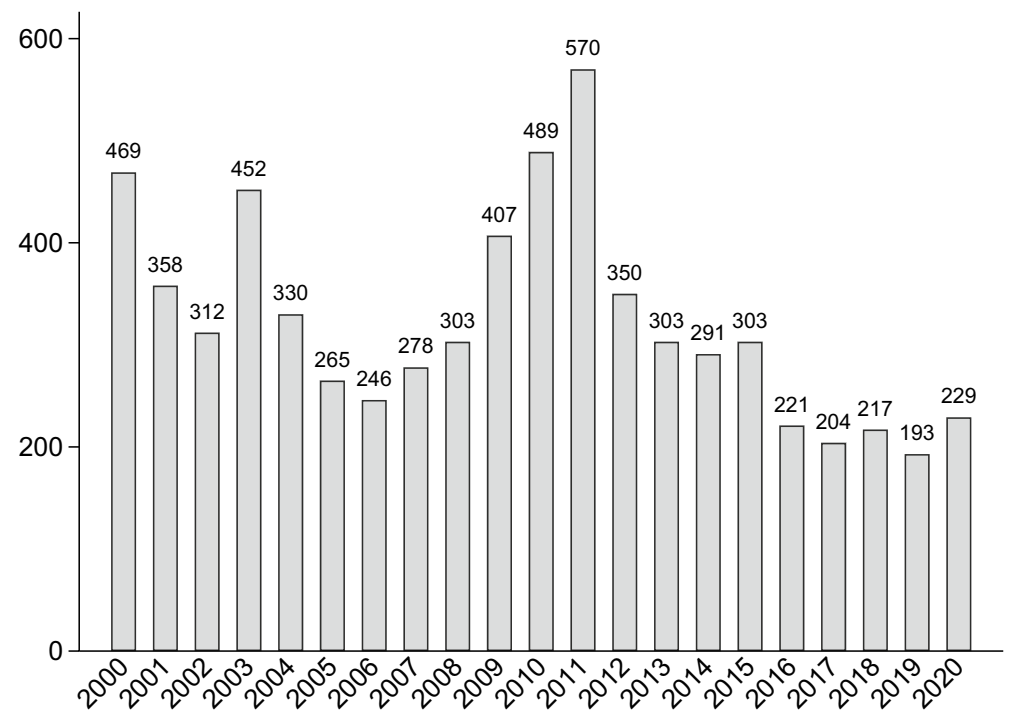

Fig. 1 Number of piracy incidents per year. The figure shows the total number of piracy incidents per year. Sample periods: 2000-2006 (exports and choice of transport mode) and 2015-2020 (ship positions). Data from International Maritime Organisation

positions becomes available later, so that the analysis on shipping network adjustments focuses on the period 2015 to 2020.

Overall, the figure illustrates that piracy is a frequent phenomenon in both sample periods. The reasons for occasional surges in piracy are not entirely clear, although Cariou and Wolff (2011) suspect a correlation between incidents of piracy and the level of GDP per capita as well as the development level of political rights and socio-political instability. Improved armament of pirates over time may also play a role (Bendall 2010). The overall decline in pirate activity since its peak in 2011 is, however, attributed to increased naval presence and improved protection of vessels including through armed guards and increased cruise speeds (ICC IMB 2013; Winn and Lewis 2017).

Figure 1 hides the strong degree of heterogeneity across regions. For the sample period 2000 to 2006, Fig. 2 thus shows the total number of piracy incidents by region. With only one observed case in the China Sea and 497 in the Indian Ocean, the map indicates substantial cross sectional variation. While piracy declined in some regions such as the South China Sea-maybe due to increased naval presence-it actually increased in others such as East Africa (Fig. 6 in the Appendix). ${ }^{5}$

The three regions most affected by piracy between 2000 and 2006 are the South China Sea with an average of 118 incidents per year, the Indian Ocean (71 incidents per annum) and the Malacca Strait (49 incidents per annum). Piracy

\footnotetext{
${ }^{5}$ Since not all piracy incidents are reported (Berg et al. 2006; Murphy 2007), all numbers constitute a lower bound for pirate activity.
} 


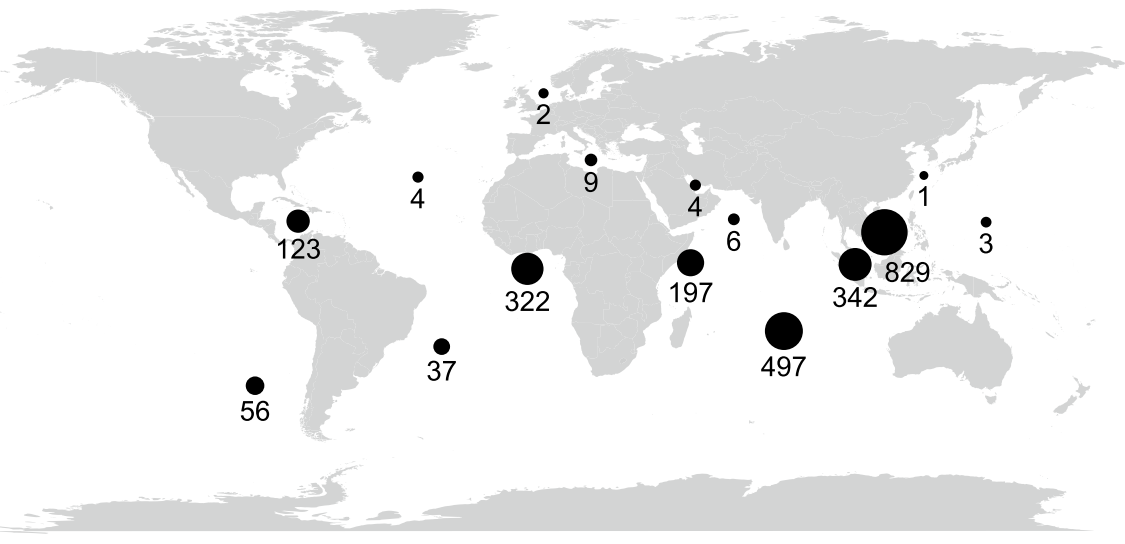

Fig. 2 The number of piracy incidents by region, 2000-2006. Note: The map shows the total number of piracy incidents from 2000 to 2006 by region. South America is subdivided into three regions. Data from International Maritime Organisation

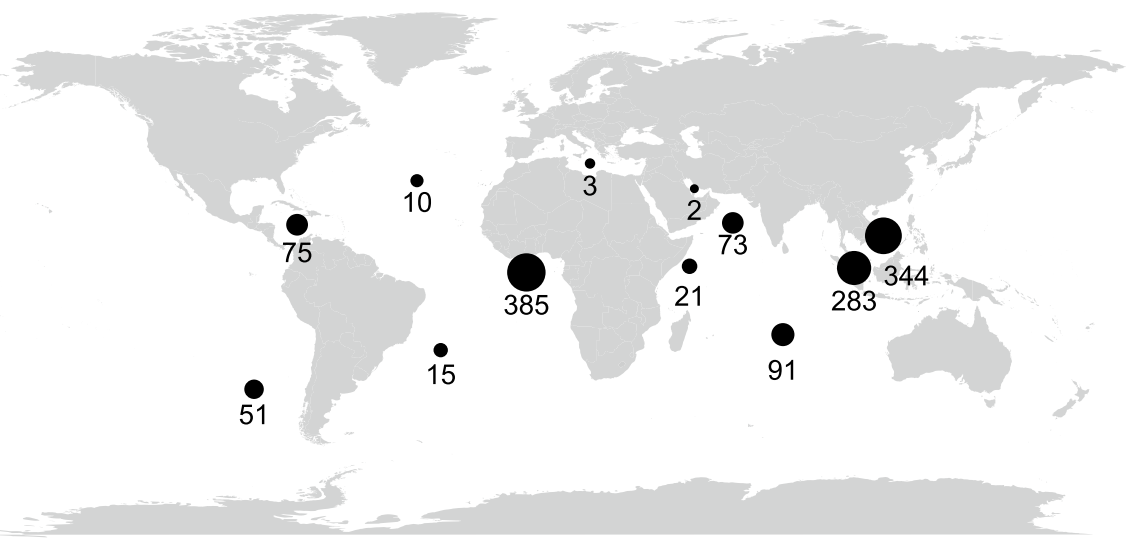

Fig. 3 The number of piracy incidents by region, 2015-2020. Note: The map shows the total number of piracy incidents from 2015 to 2020 by region. South America is subdivided into three regions. Data from International Maritime Organization

along the Coast of Somalia (East Africa, 29 incidents per year) is not among the top three affected regions, as pirate activity there only increased dramatically in 2008 and 2009. Given that monthly export data is only available to us from 2000 to 2006, we have to limit our analysis to this time period. ${ }^{6}$ Nevertheless, there is no reason to believe that firms should react differently to a piracy incident today than they did in the period of investigation. In addition, even though piracy

\footnotetext{
${ }^{6}$ Export data for the years 2007 to 2009 is available at the annual level. However, aggregating to the annual level would substantially reduce variation over time.
} 


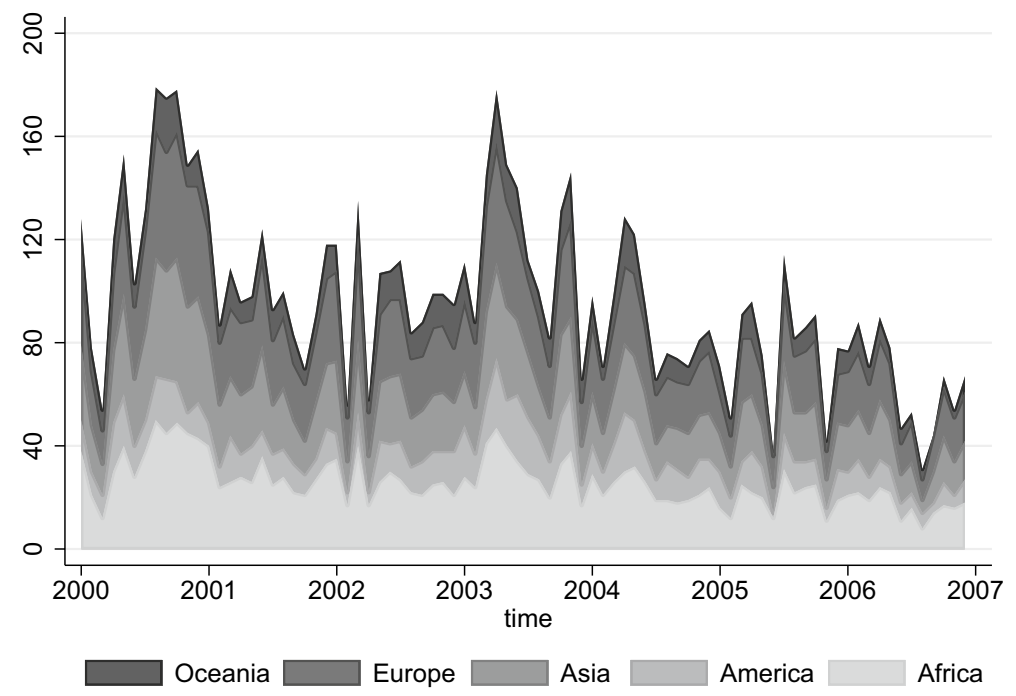

Fig. 4 Number of piracy incidents over time by destination continent. Note: The graph shows the total number of reported piracy incidents per month, covering all possible routes from China to each of the five destination continents. Data from International Maritime Organisation

declined since its peak in 2011 (Fig. 1), the average number of incidents per year in 2015 to 2020 (228 cases p.a.) is comparable to the average in 2000 to 2006 (348 cases p.a.).

Figure 3 replicates the previous map on the regional distribution of pirate attacks, but uses data from 2015 to 2020. South East Asia including the Straight of Malacca remains the most affected region. Compared to the the years 2000 to 2006, however, the number of incidents per year decreases for the Indian Ocean and increases for Western Africa.

Matching the Chinese customs data with the piracy data is a challenge because there are often several routes linking China to a destination country. For example, goods can be shipped from China to France either through the Suez Canal or by going around Africa along the Cape of Good Hope. The choice of route depends on several factors, including distance, weather conditions, duties, whether or not the ship calls at certain ports for loading and unloading of additional freight and of course the risk of piracy. It is thus not evident which route a ship takes.

This paper applies a conservative approach, considering all possible ocean routes between China and the continent to which the destination country belongs. The number of piracy incidents on the route between China and the destination continent is taken to be the sum of all piracy incidents in all areas covered by the possible ocean routes. Information on the exact matching between areas affected by piracy and destination continent is provided in Table 7 in the Appendix. Even though this reduces the cross sectional variation in piracy incidents to five continents, Fig. 4 nevertheless shows that there remains significant variation both across continents and over time. The average number of piracy incidents per month between 2000 and 
2006 was 26 along all routes to Africa, 12 for America, 22 for Asia, 26 for Europe and 10 for Oceania.

There are two obvious drawbacks to this approach. First, it is possible that all or most piracy incidents are observed at a route which is not the preferred route anyway. In this case, the choice of shipment mode should be independent of the number of piracy incidents, leading to an underestimation of the treatment effect. The results presented in this paper should thus be seen as a lower bound of the effect and a first step towards estimating the impact of piracy on trade and the choice of transport mode.

Second, when using the customs data, it is impossible to observe a switch in shipping routes. A switch from one route to another due to increased pirate activity along the first one would not be picked up by the regressions, as the variation takes place at a more disaggregated level than the one observed in the data. However, a switch from one ocean route to another ocean route would affect neither air travel nor the overall value of goods shipped by ocean. As long as the destination continent stays the same, whether ships continue to use old routes or switch routes following piracy should not affect regression estimates for the overall amount of goods shipped by vessel. ${ }^{7}$

Both shortcomings of the customs data can be addressed by exploiting a dataset provided by Fleetmon.com. It contains daily positions of container ships derived from the maritime AIS, which monitors ship movements. ${ }^{8}$ We use information on geographic position and recorded cruising speed of container ships between 2015 and 2020. The number of positions located in areas affected by piracy are aggregated at the regional level. Similarly, the average speed per month per region is calculated using the mean of the recorded speed of all positions selected above. This allows us to investigate whether an increase in pirate activity induces ships to reroute or to increase cruising speed.

Ship positions and pirate attacks are merged by geographic location. We keep the IMO's region labels such as "South China Sea" and "Indian Ocean" as level of observation, but clean the pirate attacks using latitude and longitude information. For instance, a pirate attack that is assigned by the IMO the label "Indian Ocean", but latitude and longitude information by the IMO suggest the pirate attack occurred in the South China Sea, will be assigned "South China Sea". Within these regions, pirate attacks occur only in selected coastal areas. We manually identify these coastal subregions and only keep ship positions that fall into these subregions. Ship positions kept are also aggregated at the regional level and merged to pirate attacks by region and month.

Figure 5 illustrates the procedure for the region of the Indian Ocean. The map shows pirate attacks that are classified by the IMO as "Indian Ocean" and that according to the latitude and longitude information are, in fact, located in the Indian

\footnotetext{
7 This is only true as long as diversion to different routes does not increase demand for shipping services and thus transport costs along that alternative route, thus affecting the amount of goods shipped.

${ }^{8}$ See for example Stamer (2021) for a more detailed discussion of the dataset.
} 


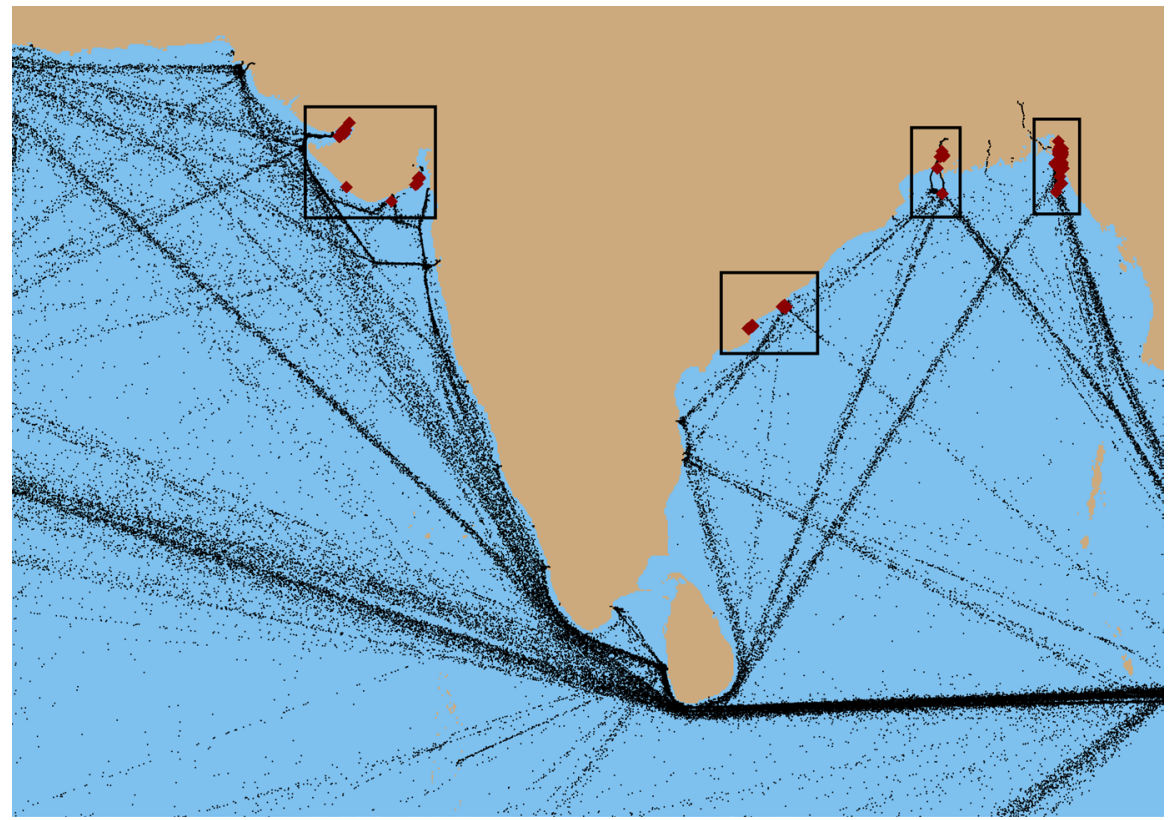

Fig. 5 Pirate attacks in the Indian Ocean, 2015-2020. Note: Black dots correspond to a single ship position in 2017 and a red diamond to a pirate attack. Black rectangles are illustrations of coastal regions used for aggregation of ship positions

Ocean. ${ }^{9}$ The black rectangles show coastal subregions, in which piracy attacks actually take place. Only ship positions in these four subregions are assigned the label "Indian Ocean" and considered for further analysis.

\section{Estimation strategy}

The effect of piracy on exports is estimated by regressing total export quantity at the destination country-product-time-level (thus aggregating over all firms) on the number of piracy incidents according to the following equation:

$$
\ln Y_{c p t}=\beta_{1} \text { Piracy }_{(t-3) c}+v_{c p}+v_{p t}+v_{c y}+v_{c m}+\epsilon_{c p t},
$$

where $\ln Y_{c p t}$ is the natural logarithm of total quantity shipped of product $p$ to destination country $c$ at time $t$. A time-unit equals a particular month in a particular year. Since such an estimation may be subject to simultaneity if more popular trade routes are more likely to attract piracy, the number of piracy incidents on a route to country $c$ at time $t$ ( Piracy $_{t c}$ ) is lagged by three months. By using country-product

9 There are several attacks classified by IMO as being in the Indian Ocean, but that also fall in areas defined by the IMO as Eastern Africa and South China Sea according to the GPS-information. 
fixed effects $v_{c p}$, the estimated coefficient $\beta_{1}$ tells us how total exports of a particular product $p$ to a particular country $c$ change at a point in time $t$ if the number of piracy incidents has changed three months ago.

Country-product fixed effects also control for all unobserved time invariant variables that may correlate with both the dependent variable and the number of piracy incidents, thus ruling out one possible source of omitted variable bias. In particular, some routes are more likely to experience piracy than others. One reason for this could be geography - natural harbours provide a good basis for piracy operations. Another is the popularity of the route as those with a lot of traffic might either attract piracy (greater likelihood of capturing a ship) or deter it (ships in distress may quickly call for help).

Global economic conditions might constitute another source of omitted variable bias. In particular, a strong global economy might be associated with an increase in shipping activity as well as a decline in pirate activity under the assumption that the latter is correlated with economic hardship (Cariou and Wolff 2011). Product-time fixed effects $v_{p t}$ control for global as well as product specific time trends.

Country-specific time trends are accounted for through country-year fixed effects $v_{c y}$. Finally, seasonal weather conditions simultaneously affect shipping and pirate activity. Since they may differ across routes at the same point in time, they are controlled for using country-month fixed effects $v_{c m} \cdot{ }^{10} \epsilon_{c p t}$ is an error term.

At the firm level, the effect of piracy on the choice of transport mode is estimated as follows:

$$
Y_{c p f t}=\beta_{1} \text { Piracy }_{t c}+\beta_{2} \ln p_{c p f t}+v_{c p f}+v_{p f t}+v_{c m}+\epsilon_{c p f t},
$$

where $Y_{c p f t}$ is a dummy (henceforth "ocean dummy") that equals one if a shipment to country $c$ from firm $f$ of good $p$ at time $t$ is carried out by ship and zero otherwise. In an alternative specification, $Y_{c p f t}$ is the natural logarithm of the size of the transaction. Piracy ${ }_{t c}$ is the number of piracy incidents on the route to country $c$ at time $t$ (not lagged). While popular routes with large trade values may cause increased pirate activity, this relationship is less likely to hold at the firm-transaction level. Average shipment size (per container) should therefore not affect piracy on the route.

Any remaining correlation is controlled for through destination country-productfirm fixed effects $v_{c p f}$. $\ln p_{c p f t}$ is the natural logarithm of the unit value of the transaction. $v_{p f t}$ are product-firm-time fixed effects and control for global economic conditions as well as product-firm-specific time trends. Destination country-month fixed effects $v_{c m}$ control for seasonal weather conditions. $\epsilon_{c p f t}$ is an error term.

It is always challenging to estimate treatment effects if the dependent variable varies along more dimensions than the explanatory variable. In this case a variable varying at the country-product-firm-time dimension is regressed on a variable that varies along the continent-time dimension. Compared to the previous regression at the product level, using the more disaggregated transaction-level data makes a clean identification even more difficult. It is therefore important to exploit as many sources

10 "Month" in this context means January-December, whereas "time" is a year-month combination. 
of variation in the explanatory variable as possible to identify a treatment effect. We therefore abstain from additionally including country-year fixed effects because, in addition to country-month and product-firm-time fixed effects, these would absorb too much of the variation needed to estimate a treatment effect.

This approach makes our estimation less conservative, relative to the productlevel regression. It could in theory constitute a source of omitted variable bias if country specific time varying trade costs correlate with both piracy as well as firms' choice of transport mode and shipment quantity. However, the principal source of omitted variable bias in this context should be seasonal weather conditions, which remain controlled for with country-month fixed effects. In addition, parts of the unobserved variables varying at the country-year dimension are captured by the inclusion of the unit value as additional regressor.

Using the natural logarithm of transaction size as dependent variable and controlling for country-product-firm fixed effects ensures that the piracy coefficient $\beta_{1}$ identifies how the average quantity of product $p$ shipped by firm $f$ to country $c$ changes with every additional piracy incident along a route connecting China to destination country $c$. Using the ocean dummy as dependent variable, $\beta_{1}$ informs about the effect of piracy on the choice of shipment mode.

Finally, the effect of piracy on the behaviour of container ships is estimated using the following equation:

$$
\ln Y_{r t}=\beta_{1} \text { Piracy }_{(t-3) r}+v_{r m}+v_{r y}+v_{t}+\epsilon_{r t},
$$

where both the dependent variable $Y_{r t}$ and the explanatory variable Piracy $_{(t-3) r}$ vary at the region and time (year-month) dimension. Region refers to the geographic sea regions as outlined above. Using this estimation strategy, we first regress the number of container ship positions on the number of pirate attacks (lagged by three months). In a second step, we investigate the effect of the lagged number of pirate attacks on the mean speed of the freight ships. Region-specific seasonal trends are captured by the region-month fixed effect $v_{r m}$, whereas medium term regional trends are captured by region-year fixed effect $v_{r y}$. Time fixed effects $v_{t}$ control for global time trends and $\epsilon_{r t}$ is an error term.

\section{Results}

\subsection{Trade effects and the choice of transport mode}

Table 1 presents the results of the regressions using the customs data. At the product-level, the significantly negative coefficient of -0.0009 reported in Column (1) implies that one additional case of piracy along a set of routes linking China to a particular destination continent is associated with a $0.1 \%$ fall in exports to all countries on that particular continent. In an average month with 26 piracy cases along all routes to Europe, trade is around $2.3 \%$ lower than in the absence of piracy.

This aggregate effect is driven by a reduction in ocean trade. While ocean trade declines by $0.11 \%$ following an additional piracy incident (Column 2 ), the respective 
Table 1 Effects of piracy on Chinese exporters

\begin{tabular}{|c|c|c|c|c|c|c|c|}
\hline \multirow{4}{*}{ Dep. var. } & (1) & (2) & (3) & (4) & $(5)$ & (6) & (7) \\
\hline & \multirow{2}{*}{\multicolumn{3}{|c|}{$\frac{\text { Product-level }}{\ln (\text { export quantity) }}$}} & \multicolumn{4}{|c|}{ Firm-transaction-level } \\
\hline & & & & \multirow{2}{*}{$\begin{array}{l}\text { Dummy } \\
\text { Ocean }\end{array}$} & \multicolumn{3}{|c|}{$\ln$ (shipment quantity) } \\
\hline & All & Ocean & Air & & All & Ocean & Air \\
\hline $\begin{array}{l}\text { Piracy } \\
\text { cases }\end{array}$ & $\begin{array}{l}-0.0009 * * \\
(0.0004)\end{array}$ & $\begin{array}{l}-0.0011^{* * * *} \\
(0.0003)\end{array}$ & $\begin{array}{l}-0.0011 \\
(0.0008)\end{array}$ & $\begin{array}{l}-0.0002 * * * \\
(0.0000)\end{array}$ & $\begin{array}{l}0.0006 * * \\
(0.0003)\end{array}$ & $\begin{array}{l}0.0013 \text { *** } \\
(0.0003)\end{array}$ & $\begin{array}{l}-0.0001 \\
(0.0010)\end{array}$ \\
\hline $\ln$ (price) & & & & $\begin{array}{l}-0.0474 * * * \\
(0.0008)\end{array}$ & $\begin{array}{l}-0.6738^{* * * *} \\
(0.0041)\end{array}$ & $\begin{array}{l}-0.6849 * * * \\
(0.0039)\end{array}$ & $\begin{array}{l}-0.5159 * * * \\
(0.0079)\end{array}$ \\
\hline$v_{c p}$ & Yes & Yes & Yes & No & No & No & No \\
\hline$v_{p t}$ & Yes & Yes & Yes & No & No & No & No \\
\hline$v_{c y}$ & Yes & Yes & Yes & No & No & No & No \\
\hline$v_{c m}$ & Yes & Yes & Yes & Yes & Yes & Yes & Yes \\
\hline$v_{c p f}$ & No & No & No & Yes & Yes & Yes & Yes \\
\hline$v_{p f t}$ & No & No & No & Yes & Yes & Yes & Yes \\
\hline $\begin{array}{l}\text { Observa- } \\
\text { tions }\end{array}$ & $4,896,465$ & $3,770,565$ & $1,019,446$ & $10,614,035$ & $10,614,035$ & $8,126,992$ & $1,436,978$ \\
\hline$R^{2}$ & 0.6346 & 0.8071 & 0.7852 & 0.5773 & 0.8026 & 0.8598 & 0.8594 \\
\hline
\end{tabular}

(1)-(3): Piracy cases lagged by three months. Robust standard errors clustered by country-product(-firm) in parentheses. $* * * p<0.01, * * p<0.05, * p<0.1$

coefficient for air trade (Column 3) is not statistically significant. The results are comparable in magnitude to those of Bensassi and Martínez-Zarzoso (2013). Assuming a long-run elasticity of trade with respect to freight rates of 0.058 (Friedt and Wilson 2020), their estimate of the effect of hijacking a ship on transport cost $(1.2 \%)$ translates into a $0.07 \%$ trade reduction following one such incident.

The results of the firm-transaction-level regressions are reported in Columns (4) to (7) of Table 1. Column (4) presents results from regressing the ocean dummy, which identifies whether a transaction has been carried out by ship as opposed to air, on the number of piracy incidents. The coefficient of ln price is negative and highly significant, indicating that a $1 \%$ increase in export unit values is associated with a reduction in the likelihood of the transaction being carried out by sea by 4.7\%. Qualitatively, this result is in line with the finding of Harrigan (2010).

The negative piracy coefficient of -0.0002 , significant at the $1 \%$ level, indicates that one additional piracy incident along a set of routes linking China to a particular destination continent reduces the probability that a given firm ships a given product to a particular country on that continent by ship by $0.02 \%$. This result provides evidence that increased pirate activity induces firms to reduce the number of transactions carried out by ship relative to those by plane.

Column (5) presents the effects of piracy on average shipment size. The statistically significant coefficient of 0.0006 implies that the average quantity shipped increases by $0.06 \%$ for each piracy incident on the set of routes linking China to a particular destination continent. This coefficient is twice as large for goods shipped by sea (Column 6) and insignificant for air shipments (Column 7). The findings are in line with our theoretical considerations following Kropf and Sauré (2014). Piracy 
Table 2 Effects of piracy on ship behaviour

\begin{tabular}{lllllll}
\hline Dep. var. & $(1)$ & $(2)$ & $(3)$ & $(4)$ & $(5)$ & $(6)$ \\
& $\ln$ (ship positions) & \multicolumn{3}{l}{ ln(mean speed) } \\
\hline Piracy cases & $0.205^{* * *}$ & $-0.009^{* * *}$ & $-0.005^{* *}$ & $-0.029^{* *}$ & $0.005^{* *}$ & 0.002 \\
& $(0.038)$ & $(0.003)$ & $(0.002)$ & $(0.013)$ & $(0.002)$ & $(0.002)$ \\
$v_{r m}$ & No & Yes & Yes & No & Yes & Yes \\
$v_{r y}$ & No & No & Yes & No & No & Yes \\
$v_{t}$ & No & No & Yes & No & No & Yes \\
Observations & 759 & 759 & 759 & 759 & 759 & 759 \\
$R^{2}$ & 0.217 & 0.989 & 0.996 & 0.031 & 0.907 & 0.965 \\
\hline
\end{tabular}

Piracy cases lagged by three months. Robust standard errors clustered by region-year in parentheses. $* * *$ $p<0.01, * * p<0.05, * p<0.1$

increases fixed costs per shipment and thus induces firms to reduce shipment frequency and increase shipment size. The results also match the framework provided by Békés et al. (2017). Piracy constitutes a source of uncertainty for shipping companies, resulting in larger and less frequent shipments.

\subsection{Effects on ship behaviour}

Table 2 presents the regression results for the behaviour of the container shipping network. Columns (1) to (3) display the estimated effects of piracy on the number of ship positions recorded in the respective sea regions. Column (3) shows results for the baseline regression specification. The significantly negative coefficient of -0.005 implies that one additional pirate attack in a given region during a given month reduces the number of ship positions in that region three months later by $0.5 \%$.

This result confirms previous findings that pirate attacks negatively affect ocean going trade. Two mechanisms may account for this result: First, ships may be rerouted around areas with pirate attacks. Second, it is also possible that fewer sips began their voyages in the first place. As many pirate attacks occur near ports or in choke points of maritime trade routes such as the strait of Malacca, re-routing may in many cases not be viable.

Not incorporating fixed effects results in a significantly positive coefficient (Column 1 of Table 2). As suspected, pirate attacks clearly occur in areas with a larger number of container ships. Including region-month fixed effects corrects for this source of endogeneity, so that the estimated coefficient turns negative (Column 2).

Regression results using average cruising speed of container ships as dependent variable are reported in Columns (4) to (6) of Table 2. The estimated coefficient in the baseline specification (Column 6) is not significantly different from zero, indicating that piracy does not affect cruising speed of ships in affected regions. However, it should be noted that an increase in cruising speed is only picked up by the regression if the ship remains in the same region. In case ships simultaneously 
Table 3 Effects of piracy on Chinese export prices

\begin{tabular}{lllllll}
\hline & $(1)$ & $(2)$ & $(3)$ & $(4)$ & $(5)$ & $(6)$ \\
& All & Ocean & Air & All & Ocean & Air \\
\hline Piracy cases & -0.00015 & -0.00014 & -0.0001 & $-0.00018^{*}$ & $-0.00017^{*}$ & -0.0001 \\
& $(0.0001)$ & $(0.0001)$ & $(0.0004)$ & $(0.0001)$ & $(0.0001)$ & $(0.0004)$ \\
$v_{c m}$ & Yes & Yes & Yes & No & No & No \\
$v_{c p f}$ & Yes & Yes & Yes & Yes & Yes & Yes \\
$v_{p f t}$ & Yes & Yes & Yes & Yes & Yes & Yes \\
Observations & $10,614,035$ & $8,126,992$ & $1,461,273$ & $10,614,035$ & $8,126,992$ & $1,461,519$ \\
$R^{2}$ & 0.9599 & 0.9682 & 0.9559 & 0.9599 & 0.9682 & 0.9558 \\
\hline
\end{tabular}

Dependent variable: 1 export price. Robust standard errors clustered by country-product-firm in parentheses. $* * * p<0.01, * * p<0.05, * p<0.1$

re-route and increase cruising speed, the regression specification underestimates the true effect of piracy on cruising speed.

In addition, and given the comparatively small number of observations, the wealth of fixed effects captures a large portion of the variation needed to identify a treatment effect. Using region-year fixed effects only (Column 5) results in a significantly positive coefficient. According to this specification, on additional pirate attack causees ships to increase their speed on average by $0.5 \%$. This in turn leads to higher trade costs as faster ships burn significantly more fuel per sea mile cruised. ${ }^{11}$ Not incorporating any fixed effects results in a significantly negative coefficient (Column 4) as pirates are most likely to attack ships that have a relatively low cruising speed.

\subsection{Extensions and robustness}

In an extension, we investigate the effect of piracy on export prices. Columns (1) to (3) of Table 3 show regression results with transaction price as dependent variable. Although not significantly different from zero at conventional levels of significance ( $p$ value $=0.16$ ), the coefficients in Columns (1) and (2) point towards falling average export prices as increased transport costs are absorbed partially. Since countrymonth fixed effects absorb a lot of variation (seasonality may be a driver of piracy), they are omitted in Columns (4) to (6), turning the price coefficients in Columns (4) and (5) significant. There is no evidence for a change in unit values of goods shipped by air (Columns 3 and 6).

As argued in Sect. 4, the piracy variable in the product-level regression is lagged by three months in order to address reverse causality as more popular trade routes could be targeted by pirates more often. This would lead to an underestimation of the negative treatment effect as piracy is associated with more popular routes. To show that this is indeed the case, the product-level regressions are carried out

\footnotetext{
11 Dagkinis and Nikitakos (2015), for instance, suggest a cubic relationship between speed and fuel consumption.
} 
Table 4 Product-level regressions with varying lags

\begin{tabular}{|c|c|c|c|c|c|c|c|c|}
\hline \multirow[t]{3}{*}{ Lag length } & (1) & (2) & (3) & (4) & (5) & (6) & (7) & (8) \\
\hline & \multicolumn{2}{|l|}{0 months } & \multicolumn{2}{|l|}{1 month } & \multicolumn{2}{|l|}{6 months } & \multicolumn{2}{|l|}{12 months } \\
\hline & All & Ocean & All & Ocean & All & Ocean & All & Ocean \\
\hline $\begin{array}{l}\text { Piracy } \\
\text { cases }\end{array}$ & $\begin{array}{l}0.0004 \\
(0.0004)\end{array}$ & $\begin{array}{l}0.0005 \\
(0.0004)\end{array}$ & $\begin{array}{l}-0.0008^{* *} \\
(0.0004)\end{array}$ & $\begin{array}{l}-0.0011^{* * *} \\
(0.0003)\end{array}$ & $\begin{array}{l}-0.0001 \\
(0.0004)\end{array}$ & $\begin{array}{l}-0.0004 \\
(0.0004)\end{array}$ & $\begin{array}{l}0.0007 * \\
(0.0004)\end{array}$ & $\begin{array}{l}0.0005 \\
(0.0003)\end{array}$ \\
\hline$\nu_{c p}$ & Yes & Yes & Yes & Yes & Yes & Yes & Yes & Yes \\
\hline$v_{p t}$ & Yes & Yes & Yes & Yes & Yes & Yes & Yes & Yes \\
\hline$v_{c y}$ & Yes & Yes & Yes & Yes & Yes & Yes & Yes & Yes \\
\hline$v_{c m}$ & Yes & Yes & Yes & Yes & Yes & Yes & Yes & Yes \\
\hline $\begin{array}{l}\text { Observa- } \\
\text { tions }\end{array}$ & $4,966,117$ & $3,825,287$ & $4,944,400$ & $3,807,830$ & $4,812,824$ & $3,707,092$ & $4,639,814$ & $3,572,745$ \\
\hline $\begin{array}{l}\text { Adj. R } \\
\text { square }\end{array}$ & 0.778 & 0.778 & 0.778 & 0.778 & 0.780 & 0.780 & 0.783 & 0.783 \\
\hline
\end{tabular}

Dependent variable: In export quantity. Piracy cases lagged by zero, one, six or twelve months. Robust standard errors clustered by country-product in parentheses. $* * * p<0.01, * * p<0.05, * p<0.1$

using contemporary rather than lagged piracy cases as the regressor. The results are reported in Columns (1) and (2) of Table 4. Estimated coefficients are positive and not significantly different from zero, indicating that not using lags indeed results in biased estimates of the treatment effect.

The product-level regression is also carried out using one, six and 12 month lags of piracy. Regression results for one month lags are reported in Columns (3) and (4) of Table 4. Estimated coefficients are similar in magnitude and significance to the baseline regression with three month lags. Estimated coefficients using 6 month lags of piracy are, however, not significantly different from zero (Columns 5 and 6), indicating that trade dampening effects of piracy are only temporary. Looking at twelve month lags (Column 7) even suggests an increase in trade, although the result is only significant at the $10 \%$ level and does not hold when only looking at ocean trade (Column 8). Overall, the results suggest that exports decline shortly after an increase in pirate activity is observed. However, this decline is relatively short lived.

The baseline firm-level regressions use contemporary piracy as the explanatory variable. In a robustness check, we regress the dummy variable indicating ocean transport, the shipment quantity as well as the shipment quantity shipped via ocean transport on piracy lagged by one, three, six and twelve months respectively. The results, reported in Table 5, are robust to most of the different lag specifications. This is particularly true for quantity shipped by ocean as well as the ocean dummy, but less so for the shipment quantity that also includes air transport. The results suggest that firm-level effects are lasting at least several months. Taken together with the product-level regression results presented in Table 4, the findings imply that while overall trade recovers around half a year after a surge in piracy, the impact on firm behaviour, i.e. sending less frequent but larger shipments, is long lasting.

In another robustness check, we perform our baseline product- and firm-level regressions using one month as well as 3 month leads of piracy. The results are reported in Table 8 in the Appendix. The estimated coefficients in Columns (1) to (4) are not significantly different from zero, indicating that piracy in period $t+1$ or 


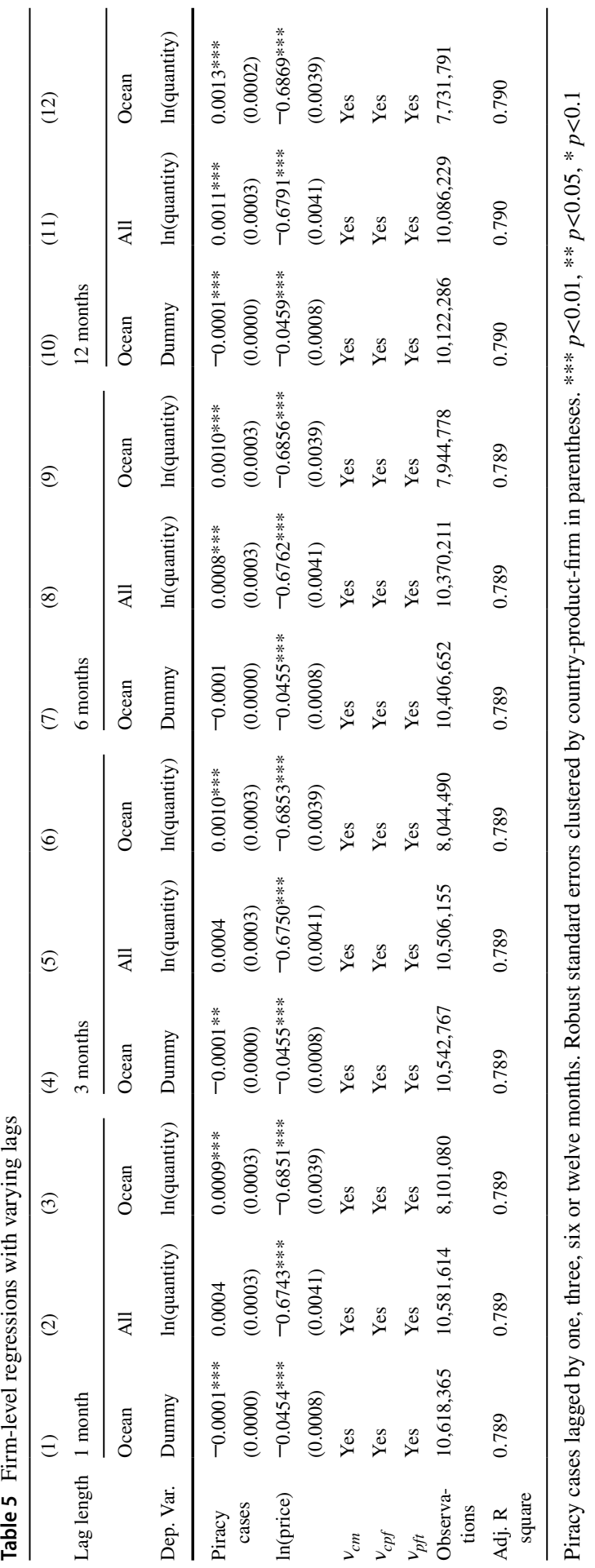


Table 6 Firm-level regressions by firm size

\begin{tabular}{llll}
\hline Dep. var. & $(1)$ & $(2)$ & $(3)$ \\
& Dummy & $\ln$ (quantity) & $\ln$ (quantity) \\
& Ocean & All & Ocean \\
\hline Piracy cases x small & $-0.0003^{* * *}$ & $0.0010^{* * *}$ & $0.0020^{* * *}$ \\
& $(0.0001)$ & $(0.0004)$ & $(0.0004)$ \\
Piracy cases x large & 0.0000 & -0.0004 & -0.0005 \\
& $(0.0001)$ & $(0.0004)$ & $(0.0004)$ \\
$\ln$ (price) & $-0.0453^{* * *}$ & $-0.6738^{* * *}$ & $-0.6849^{* * *}$ \\
& $(0.0008)$ & $(0.0041)$ & $(0.0039)$ \\
$v_{c m}$ & Yes & Yes & Yes \\
$\nu_{c p f}$ & Yes & Yes & Yes \\
$v_{p f t}$ & Yes & Yes & Yes \\
Observations & $10,652,235$ & $10,615,452$ & $8,128,156$ \\
Adj. R square & 0.788 & 0.788 & 0.788 \\
\hline
\end{tabular}

Robust standard errors clustered by country-product-firm in parentheses. *** $p<0.01, * * p<0.05, * p<0.1$

period $t+3$ does not impact export quantity at the product-level in period $t$. Surprisingly, estimated coefficients for the firm-level regressions (Columns 5 to 10) are similar in magnitude and significance to the baseline estimates, indicating anticipatory responses of firms.

It is possible that piracy affects firms differently depending on their size. In particular, small firms might be hit harder by piracy if their insurance costs are higher than those for large firms. If this was the case, small firms might be less willing to pay such costs and thus switch from ocean to air shipments. In another robustness test, we therefore divide firms into three bins according to their total sales in the year 2000. This allows us to construct three different dummies identifying what we call small, medium and large firms. Finally, we interact the dummy identifying small firms with the piracy variable. The same is done for the dummy identifying large firms. Regressing our dependent variables on these two interaction terms thus allows us to investigate whether small and large firms react differently to piracy.

The results are reported in Table 6. Results for the dummy regressions (Column 1) as well as for the quantity regressions (Columns 2 and 3 ) are significant for small firms and even larger in magnitude than the respective coefficients in the baseline regression in Table 1. In contrast, estimated coefficients for large firms are not statistically significantly different from zero. The findings suggest that small firms indeed react differently to piracy than large firms.

The database provided by the International Maritime Organization includes all piracy incidents that are reported. The severity of these incidents ranges from mere boarding attempts - that can sometimes be impeded by simply increasing cruising speed - to ships being hijacked and crew members killed. One might expect severe piracy incidents to have a stronger effect on future re-routing decisions or choices of transport mode. For every case, the database lists details on the incident, consequences for the crew, the load and the ship as well as action taken by the crew. In 
another robustness check, we therefore only consider cases for which consequences for the crew, the load or the ship are reported. ${ }^{12}$ The results are reported in Table 9 in the Appendix. All coefficients are similar to the baseline results, although the coefficient for shipment size (Column 4) turns insignificant.

Harrigan (2010) has shown that goods of high unit value are more likely to be shipped by air. Consequently, one would expect less valuable commodities to be more strongly affected by piracy. In another robustness test, we therefore separately investigate products with below median unit value and products with above median unit value. Indeed, the product-level results in the baseline regression are driven entirely by goods with below median unit values. The coefficients for these goods, reported in Columns (1) and (2) of Table 10 in the Appendix, are significantly negative and very similar in magnitude to the baseline regression. In contrast, estimated coeffcients for products of above median unit value are smaller in magnitude and not statistically significantly different from zero (Columns 3 and 4).

The estimated coefficients for the dummy regressions are, however, almost identical in magnitude and significance for goods of low unit value (Column 5) and high unit value (Column 8). The firm-level decision to switch from ocean to air transport therefore does not seem to vary with the unit values of the goods transported. The same is not true for the effect of piracy on the average size per shipments. While the estimated coefficients for low price goods are statistically significant and even larger in magnitude than the baseline estimates (Columns 6 and 7), the coefficients for high price goods are once again not statistically significant (Columns 9 and 10). Overall, the results indicate that low price goods are on average more strongly affected by piracy than high price goods.

The baseline regression only compares ocean and air transportation. As a robustness test, the regressions are run on a sample including transportation by sea, road and rail (excluding air). The results are reported in Columns (1) to (3) of Table 11 in the Appendix. Results for the product-level regressions (Column 1) and shipment size (Column 3) are comparable to the baseline. The coefficient for the dummy estimation (Column 2) turns positive and significant, suggesting a switch away from road and rail towards ocean transport following an increase in pirate activity. This counter-intuitive result could be driven by an unobserved correlation between piracy and armed robberies.

Results at the product-level remain similar when including all four modes of transport (Column 4 of Table 11). In addition to changes in exports transported by sea or air (Columns 2 and 3 of Table 1) we now also estimate effects of piracy on the export of goods transported by rail and road. The significantly positive coefficient reported in Column 5 of Table 11 implies that an increase in pirate activity along a set of routes linking China to a destination country increases export quantity to that country for goods transported by rail. Piracy thus diverts trade from ocean to rail, which means that rail transport can be a substitute to ocean transport. This is, however not true for goods shipped by road (Column 6). The substitutability of ocean and rail transport is particularly relevant in light of China's Belt and Road initiative that-among other thingsaims to improve the railway infrastructure between China and Europe and that could lead to significant shifts in transportation modes from ship to train (Garcia-Herrero et al. 2020; Felbermayr et al. 2019; de Soyres et al. 2019).

\footnotetext{
12 These include-but are not limited to-freight being stolen, the ship being hijacked, members of the crew being injured, kidnapped or killed.
} 
Results for the firm-level dummy regressions are reported in Table 12. Once again, the results indicate a switch to ocean transport (Column 1) but also to air transport (Column 2) and rail (Column 3, magnitude only becomes visible beyond the fourth decimal place). These modes of transport become preferred relative to road (Column 4). The coefficient for average shipment quantity (Column 5) turns insignificant. This provides further evidence that the significant coefficient in Column (5) of Table 1 is driven purely by the increase in ocean shipments. Piracy does not seem to have an impact on the size of the shipments transported by rail (Column 6), while the impact on shipment size for road transport is negative (Column 7).

\section{Conclusion}

Even though piracy has disappeared from the news, it is still a frequent phenomenon and the costs associated with it remain as relevant as ever. This paper combines Chinese customs data as well as ship position data with detailed information on pirate activity to investigate the effects of piracy on trade flows. It shows that trade declines along routes affected by piracy (2.3\% for exports to Europe). Given the sources of measurement error due to data availability, this estimate is likely to constitute a lower bound of the true treatment effect.

In line with theoretical considerations, an increase in piracy along a trade route induces exporters to switch from ocean to air transport, while the remaining ocean shipments become larger. This, however, is only true for small firms. There is also some-albeit limited-evidence for a fall in average export prices, indicating that a piracy induced increase in transport costs is not fully passed on to consumers. While overall trade recovers around half a year after the piracy incident, the impact on firm behaviour is long lasting.

Last but certainly not least, the paper shows a decline in the number of container ships traveling though regions that have previously experienced a surge in pirate activity. The results imply that ships respond to piracy by re-routing. Together with (albeit limited) evidence that ships increase cruising speed following an increase in the number of piracy cases, it becomes clear that piracy imposes costs on shipping companies by means of higher fuel consumption and travel-time.

Overall, the results show that piracy does have a small but significant dampening impact on trade. Beyond obvious humanitarian reasons, this constitutes an additional motive for governments to act. Potential responses include a multilateral and coordinated approach to increase naval presence along routes frequently prone to pirate attacks. In the long term, the root of the problem might be tackled by improving living conditions and socio-political stability in the countries from which pirates operate.

The paper's findings also shed some light on more recent threats faced by deep sea shipping. Potential terrorist attacks along the Suez Canal or tensions between governments resulting in attacks on ships in the Strait of Hormuz may have very similar implications on trade and transport as piracy. Policy makers should know as much as they possibly can on how such events distort global shipping in order to minimise their impact on the way we trade. 


\section{Appendix}

Figure 6.

Tables 7, 8, 9, 10, 11, 12.
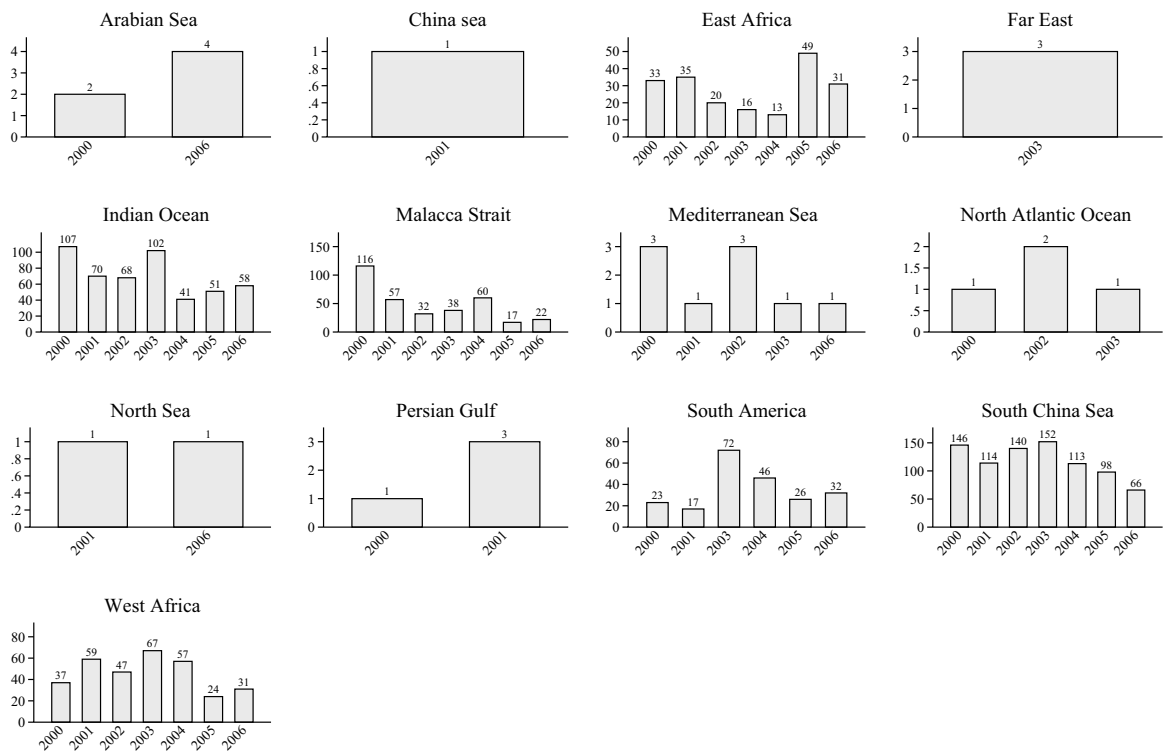

Fig. 6 Number of piracy incidents over time by region. Note: The graph reports the total number of piracy incidents from 2000 to 2006 by region. Data from International Maritime Organization

Table 7 Matching of regions to destination continents

\begin{tabular}{|c|c|c|c|c|c|}
\hline Continent & Region & Continent & Region & Continent & Region \\
\hline Africa & $\begin{array}{l}\text { East Africa } \\
\text { China Sea } \\
\text { South China Sea } \\
\text { Malacca Strait } \\
\text { Far East } \\
\text { Indian Ocean } \\
\text { West Africa }\end{array}$ & Europe & $\begin{array}{l}\text { China Sea } \\
\text { South China Sea } \\
\text { Malacca Strait } \\
\text { Far East } \\
\text { Indian Ocean } \\
\text { Arabian Sea } \\
\text { Mediterranean Sea } \\
\text { West Africa } \\
\text { North Atlantic Ocean } \\
\text { North Sea } \\
\text { East Africa }\end{array}$ & Asia & $\begin{array}{l}\text { China Sea } \\
\text { South China Sea } \\
\text { Malacca Strait } \\
\text { Far East } \\
\text { Indian Ocean } \\
\text { Arabian Sea } \\
\text { Persian Gulf } \\
\text { East Africa }\end{array}$ \\
\hline Americas & $\begin{array}{l}\text { China Sea } \\
\text { South China Sea } \\
\text { South America }\end{array}$ & Oceania & $\begin{array}{l}\text { China Sea } \\
\text { South China Sea } \\
\text { Far East }\end{array}$ & & \\
\hline
\end{tabular}

Note: Authors' own allocation 


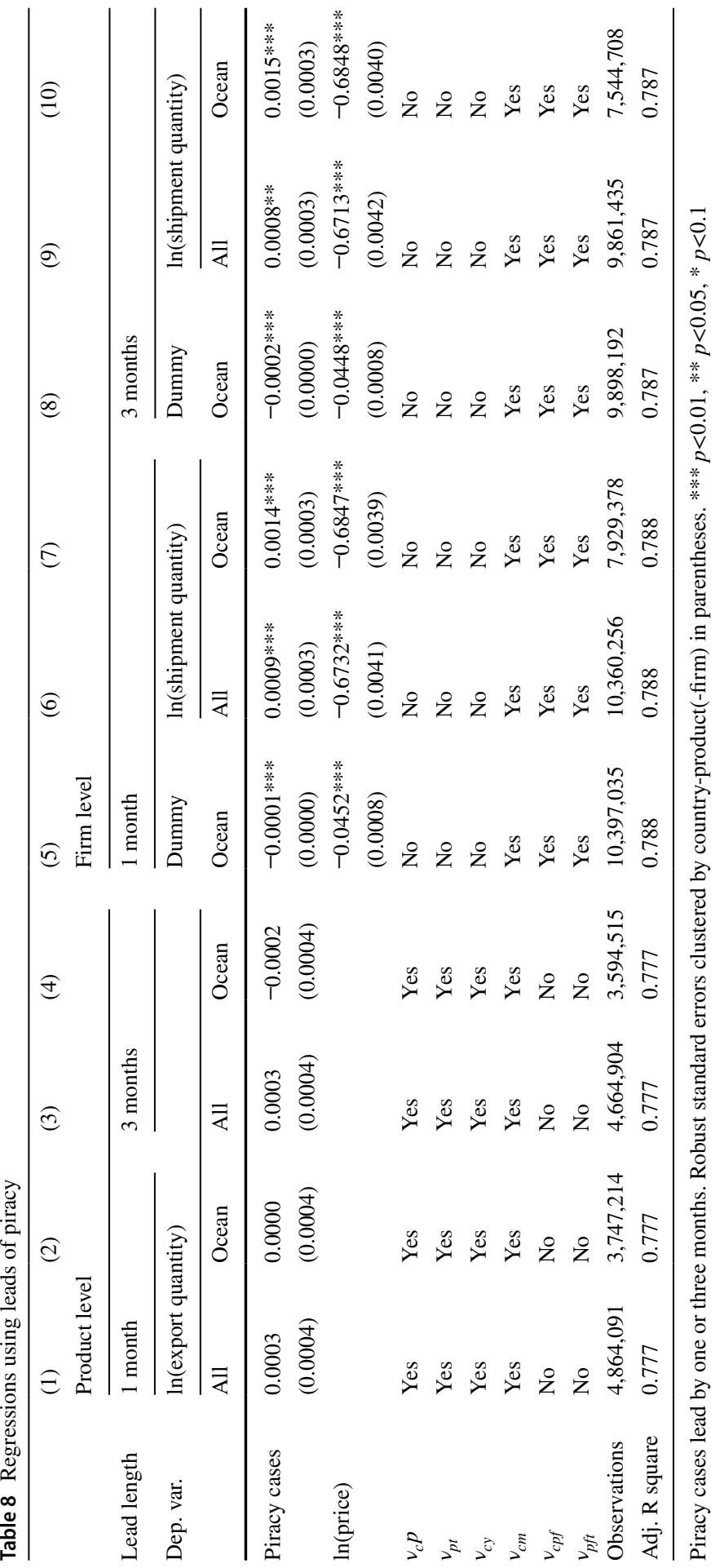


Table 9 Serious incidents only

(1) (2) (3) $\quad$ (4) $\quad$ (5)

Product level Firm-transaction level

\begin{tabular}{|c|c|c|c|c|c|}
\hline \multirow[t]{2}{*}{ Dep. var. } & \multicolumn{2}{|c|}{$\ln ($ export quantity) } & \multirow{2}{*}{$\begin{array}{l}\text { Dummy } \\
\text { Ocean }\end{array}$} & \multicolumn{2}{|c|}{$\ln$ (shipment quantity) } \\
\hline & All & Ocean & & All & Ocean \\
\hline Piracy cases & $\begin{array}{l}-0.0009^{* * *} \\
(0.0003)\end{array}$ & $\begin{array}{l}-0.0010^{* * *} \\
(0.0003)\end{array}$ & $\begin{array}{l}-0.0002 * * * \\
(0.0000)\end{array}$ & $\begin{array}{l}0.0004 \\
(0.0003)\end{array}$ & $\begin{array}{l}0.0010^{* * *} \\
(0.0003)\end{array}$ \\
\hline $\ln ($ price $)$ & & & $\begin{array}{l}-0.0453 * * * \\
(0.0008)\end{array}$ & $\begin{array}{l}-0.6739 * * * \\
(0.0041)\end{array}$ & $\begin{array}{l}-0.6849 * * * \\
(0.0039)\end{array}$ \\
\hline$v_{c p}$ & Yes & Yes & No & No & No \\
\hline$v_{p t}$ & Yes & Yes & No & No & No \\
\hline$v_{c y}$ & Yes & Yes & No & No & No \\
\hline$v_{c m}$ & Yes & Yes & No & No & No \\
\hline$v_{c p f}$ & No & No & Yes & Yes & Yes \\
\hline$v_{p f t}$ & No & No & Yes & Yes & Yes \\
\hline$v_{c m}$ & No & No & Yes & Yes & Yes \\
\hline Observations & $4,896,465$ & $3,770,565$ & $10,650,819$ & $10,614,035$ & $8,126,992$ \\
\hline Adj. R square & 0.779 & 0.779 & 0.788 & 0.788 & 0.788 \\
\hline
\end{tabular}

(1)-(2): Piracy cases lagged by three months. Robust standard errors clustered by country-product(-firm) in parentheses. *** $p<0.01, * * p<0.05, * p<0.1$ 


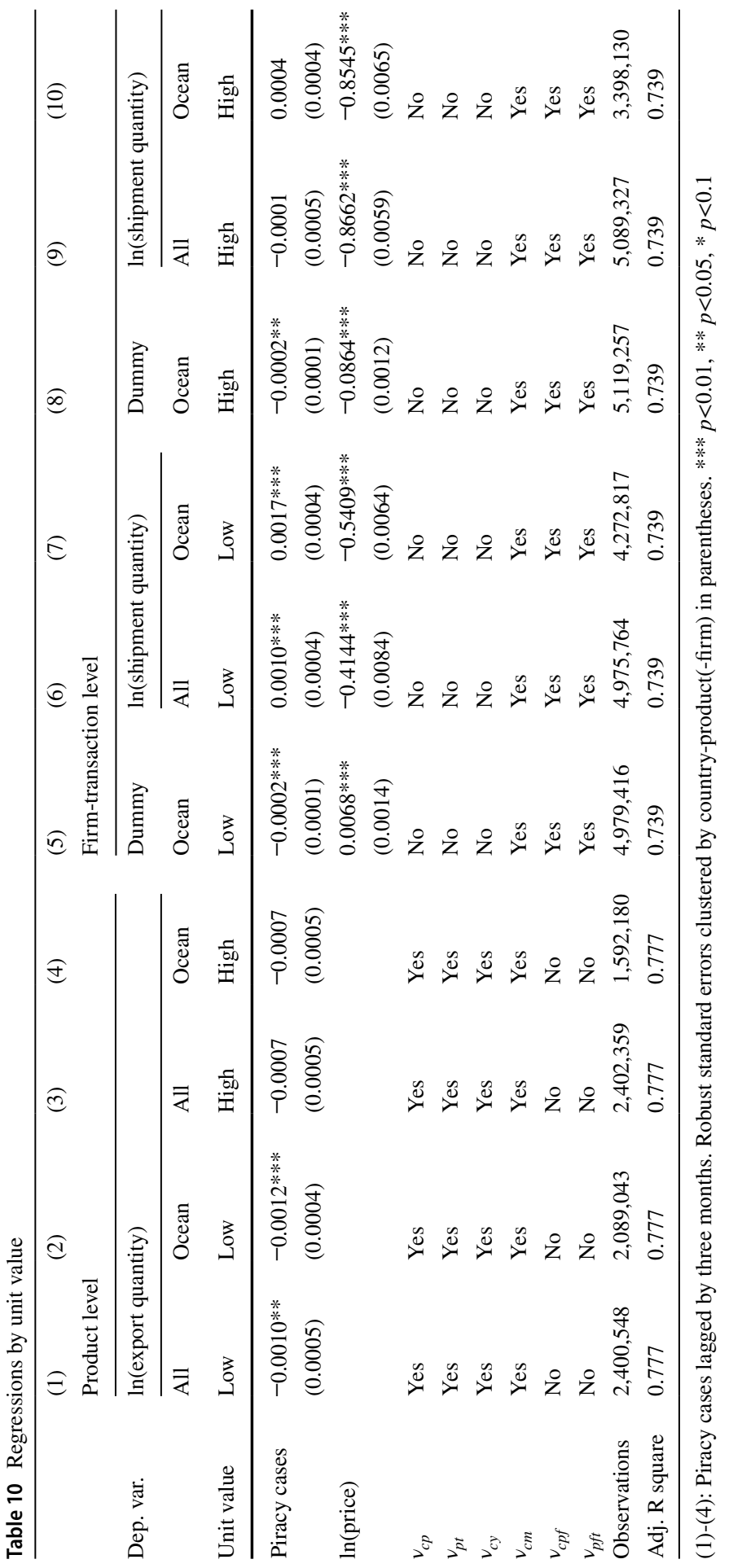


Table 11 Including exports via rail and road

\begin{tabular}{|c|c|c|c|c|c|c|}
\hline \multirow{4}{*}{ Dep. var. } & \multirow{3}{*}{$\begin{array}{l}\text { (1) } \\
\text { Product level } \\
\ln \text { (quantity) }\end{array}$} & (2) & (3) & (4) & (5) & \multirow[t]{2}{*}{ (6) } \\
\hline & & \multicolumn{2}{|c|}{ Firm-transaction level } & \multicolumn{2}{|l|}{ Product level } & \\
\hline & & Dummy & $\ln$ (quantity) & $\ln$ (quantity) & $\ln$ (quantity) & $\ln$ (quantity) \\
\hline & All & Ocean & All & All & Rail & Road \\
\hline \multirow[t]{2}{*}{ Piracy cases } & $-0.0012 * * *$ & $0.0005 * * *$ & $0.0007 * * *$ & $-0.0010^{* * *}$ & $0.0243^{* *}$ & -0.0001 \\
\hline & $(0.0003)$ & $(0.0000)$ & $(0.0003)$ & $(0.0003)$ & $(0.0115)$ & $(0.0007)$ \\
\hline \multirow[t]{2}{*}{$\ln ($ price $)$} & & $-0.0024 * * *$ & $-0.6683 * * *$ & & & \\
\hline & & $(0.0004)$ & $(0.0037)$ & & & \\
\hline$v_{c p}$ & Yes & No & No & Yes & Yes & Yes \\
\hline$v_{c t}$ & Yes & No & No & Yes & Yes & Yes \\
\hline$v_{c y}$ & Yes & No & No & Yes & Yes & Yes \\
\hline$v_{c m}$ & Yes & Yes & Yes & Yes & Yes & Yes \\
\hline$v_{c p f}$ & No & Yes & Yes & No & No & No \\
\hline$v_{p f t}$ & No & Yes & Yes & No & No & No \\
\hline Observations & $4,715,197$ & $10,093,647$ & $10,079,941$ & $5,840,805$ & 7,555 & 811,722 \\
\hline Adj. R square & 0.703 & 0.788 & 0.788 & 0.703 & 0.763 & 0.763 \\
\hline
\end{tabular}

(1) and (4)-(6): Piracy cases lagged by three months. (1)-(3) include transport by sea, road and rail. (4) - (6) additionally include air transport. Robust standard errors clustered by country-product(-firm) in parentheses. *** $p<0.01, * * p<0.05, * p<0.1$ 


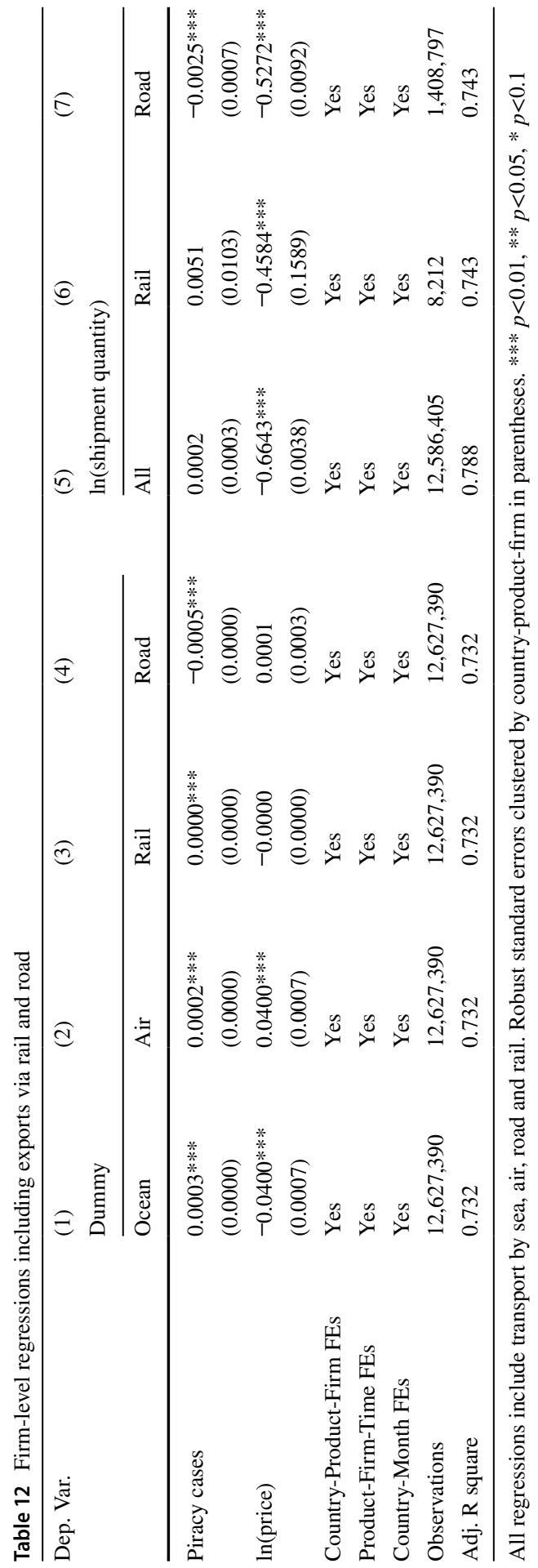


Funding Open Access funding enabled and organized by Projekt DEAL.

Open Access This article is licensed under a Creative Commons Attribution 4.0 International License, which permits use, sharing, adaptation, distribution and reproduction in any medium or format, as long as you give appropriate credit to the original author(s) and the source, provide a link to the Creative Commons licence, and indicate if changes were made. The images or other third party material in this article are included in the article's Creative Commons licence, unless indicated otherwise in a credit line to the material. If material is not included in the article's Creative Commons licence and your intended use is not permitted by statutory regulation or exceeds the permitted use, you will need to obtain permission directly from the copyright holder. To view a copy of this licence, visit http://creativecommons.org/licen ses/by/4.0/.

\section{References}

Arslanalp, S., Marini, M., \& Tumbarello, P. (2019). Big data on vessel traffic: Nowcasting trade flows in real time. IMF Working Paper 275.

Békés, G., Fontagné, L., Muraközy, B., \& Vicard, V. (2017). Shipment frequency of exporters and demand uncertainty. Review of World Economics, 153(4), 779-807.

Bendall, H. B. (2010). Cost of piracy: A comparative voyage approach. Maritime Economics and Logistics, 12(2), 178-195.

Bensassi, S., \& Martínez-Zarzoso, I. (2012). How costly is modern maritime piracy to the international community? Review of International Economics, 20(5), 869-883.

Bensassi, S., \& Martínez-Zarzoso, I. (2013). The price of modern maritime piracy. Defence and Peace Economics 24 (5).

Berg, D., Artmann, T., Kratz, T., Lührmann, K., Mast, E., \& Milberg, A. (2006). Piraterie - Bedrohung auf See Eine Risikoanalyse. MunichRe: Tech. rep.

Bowden, A., Hurlburt, K., Aloyo, E., Marts, C., \& Lee, A. (2010). The economic costs of maritime piracy. One earth future working paper (December).

Brancaccio, G., Kalouptsidi, M., \& Papageorgiou, T. (2017). Geography, search frictions and endogenous trade costs. CEPR Discussion Papers 12141.

Cariou, P., \& Wolff, F. C. (2011). A longitudinal analysis of piracy in shipping. Economics Bulletin, 31(2), 1055-1062.

Cerdeiro, D. A., Komaromi, A., Liu, Y., \& Saeed, M. (2020). World seaborne trade in real time: A proof of concept for building AIS-based nowcasts from scratch. IMF Working Paper 057.

Chalk, P. (2008). The maritime dimension of international security. Tech. rep.

Dagkinis, I., \& Nikitakos, N. (2015). Slow steaming options investigation using multi criteria decision analysis method. ECONSHIP 2015 Chios Greece.

de Soyres, F., Mulabdic, A., Murray, S., Rocha, N., \& Ruta, M. (2019). How much will the Belt and Road Initiative reduce trade costs? International Economics, 159(July), 151-164.

Endler, J., Engerer, H., Gössler, M., \& Pfeiffer, P. (2012). Ökonomische Aspekte von Piraterie und maritimem Terrorismus. DIW Berlin: Tech Rep.

Felbermayr, G., Sandkamp, A., Liu, W.-H., Bickenbach, F., \& Goldbeck, M. (2019). Megatrends im Welthandel: Die neue Seidenstraße - Wachstumsregion zwischen Europa und Asien Studie. IHK München und Oberbayern.

Friedt, F. L., \& Wilson, W. W. (2020). Trade, transport costs and trade imbalances: An empirical examination of international markets and backhauls. Canadian Journal of Economics, 53(2), 592-636.

Fu, X., Ng, A. K. Y., \& Lau, Y.-Y. (2010). The impacts of maritime piracy on global economic development: the case of Somalia. Maritime Policy and Management, 37(7), 677.

Garcia-Herrero, A., Wolff, G., Xu, J., Poitier, N., Felbermayr, G., Liu, W.-H., Sandkamp, A., \& Langhammer, R. (2020). EU-China trade and investment relations in challenging times. European Parliament (May).

Ge, Y., Lai, H., Lu, C.-H \& Zhu, S. C. (2014). Transportation mode and exporter heterogeneity (July).

Gilpin, R. (2009). Counting the costs of Somali Piracy. United States Institute of Peace Working Paper.

Harrigan, J. (2010). Airplanes and comparative advantage. Journal of International Economics, 82(2), 181-194.

Hastings, J. V. (2009). Geographies of state failure and sophistication in maritime piracy hijackings. Political Geography, 28(4), 213-223. 
Heiland, I., Moxnes, A., Ulltveit-Moe, Helene, K., \& Zi, Y. (2019). Trade from space: Shipping networks and the global implications of local shocks. CEPR Discussion Papers 14193.

Hornok, C., \& Koren, M. (2015). Administrative barriers to trade. Journal of International Economics, 96(S1), S110-S122.

Hornok, C., \& Koren, M. (2015). Per-shipment costs and the lumpiness of international trade. Review of Economics and Statistics, 97(2), 525-530.

Hummels, D. (2007). Transportation costs and international trade in the second era of globalization. Journal of Economic Perspectives, 21(3), 131-154.

Hummels, D., \& Schaur, G. (2013). Time as a trade barrier. American Economic Review, 103(7), 2935-2959.

Hummels, D., \& Skiba, A. (2004). Shipping the good apples out? An empirical confirmation of the Alchian-Allen conjecture. Journal of Political Economy, 112(6), 1384-1402.

ICC IMB (2013). Piracy and armed robbery against shipes - 2012 annual report. The ICC International Maritime Bureau, London.

ICC IMB (2018). Piracy and armed robbery against shipes - 2017 annual report. The ICC International Maritime Bureau, London.

Kropf, A., \& Sauré, P. (2014). Fixed costs per shipment. Journal of International Economics, 92(1), $166-184$.

Mbekeani, K., \& Ncube, M. (2011). Economic impact of maritime piracy. Africa Economic Brief, 2(10), $1-8$.

Mejia, M. Q., Cariou, P., \& Wolff, F.C. (2012). Piracy in shipping. In: The Blackwell Companion to Maritime Economics.

Murphy, M. (2007). Contemporary piracy and maritime terrorism: The threat to international security. London: Taylor \& Francis Ltd.

Percy, S., \& Shortland, A. (2009). The pirates of Somalia: Coastguards of anarchy. Brunel University Economnics and Finance Working Paper Series 9 (42).

Stamer, V., (2021). Thinking outside the container: A machine learning approach to forecasting trade flows. Kiel Working Paper 2179.

Towergate Insurance (2018). Troubled waters: The global price of piracy.

Winn, N., \& Lewis, A. (2017). European Union anti-piracy initiatives in the Horn of Africa: Linking land-based counter-piracy with maritime security and regional development. Third World Quarterly, $38(9), 2113-2128$.

Wong, W. F., \& Ziv, O. (2020). Entrepot: Hubs, scale, and trade costs. CESifo Working Paper 8199.

Publisher's Note Springer Nature remains neutral with regard to jurisdictional claims in published maps and institutional affiliations. 